\title{
EFFECT OF CRITICAL WEED COMPETITION PERIOD ON YIELD AND FIBER PROPERTIES OF COTTON (Gossypium barbadense, L.) IN NEW LANDS
}

\author{
(Received: 27.12.2015)
}

\author{
By \\ S. D. M. Eid, KH. A. Abou-Zied and M. A. Emara * \\ Central Laboratory for Weed Research and * Cotton Research Institute, \\ Agricultural Research. Center, Giza, Egypt.
}

\begin{abstract}
Two field experiments were conducted in a highly calcareous sandy clay loam soil at Nubaria Agric. Res. Station, Agric. Res. Center, Behera Governorate, Egypt during 2012 and 2013 seasons. The objectives were to study the effect of critical weed competition period on plant growth, seed cotton yield, its components and fiber properties of the Egyptian long-staple cotton cultivar Giza 86. The experimental design was a complete randomized block design with four replications. Each experiment included fourteen treatments in two groups, the first group included seven weed-free periods which were weed-free for the $3,6,9,12,15,18$ weeks from sowing and weed-free for the whole season, respectively, and the second included seven weed competition periods which were weed competition for the $3,6,9,12,15,18$ weeks from sowing and weed competition for the whole season, respectively. Results indicated that the fresh weight $\left(\mathrm{g} / \mathrm{m}^{2}\right)$ of broad leaf weeds, grassy weeds and total annual weeds decreased by $93.1,93.7$ and $93.3 \%$, respectively, with increasing weed removal periods to 18 weeks from sowing as compared with weed competition for the whole season treatment. Also, the effect of weed removal and weed competition periods were not statistically significant on position of $1^{s t}$ sympodial node, no. of open bolls and no. of non open bolls/plant, where as the effect was statistically significant on the plant height, no. of sympodial branches/plant and no. of monopodial branches/plant. Weed competition for the whole season reduced seed cotton yield per feddan by $41.1 \%$ as compared with weed-free for the whole season. The results showed that the critical period of weed competition to cotton crop start 3 weeks after planting and continue until 18 weeks from planting and the critical competition point where yield losses from early or late competition after 15 weeks from planting were equal. From these results, weed control strategies in cotton should be done through 3-18 weeks from planting and cotton can be considered as week competition for weeds especially in the earlier periods of growth, which extend to the fifteen week from planting. All fiber properties were not affected significantly by weed removal and weed competition periods, except fiber strength.
\end{abstract}

Key words: Weed, critical periods, cotton, growth, yield, and calcareous soils.

\section{INTRODUCTION}

Cotton is an important crop in Egypt for fibers and oil and exportation due its high value as long staple fiber. In 2013 the cultivated area with cotton reached 520.000 feddan according to the ministry of agriculture annual economic book (Anonymous 2014). Growth and yield of cotton is substantially reduced by weed competition. Cotton plants are a weak competitor for weeds due to its prolonged season especially in early growing periods. Several scientists have studied the influence of different weed species existing in cotton fields. In all cases, yield has been the most sensitive indicator of weed competition. Competition with (Cyperus esculentus) for 6 to 8 weeks reduced yield 20\% and full season competition by $34 \%$ (Buchanan and Burns, 1971 and Ghaly and El Shinnawy 1985). They mentioned that, Xanthium pensylanicum is a very serious problem weed in cotton, where at densities of 1 to 10 plants per 10 cotton plants reduced yield by more than $20 \%$ up to more than $80 \%$. Seed cotton yield in hand weeded control plots averaged $14 \%$ higher than in plots where the weeds remained throughout the season (Keely et al., 1973 and Keely and Thullen, 1975). Kempen, (1984) reported that several annual and perennial weeds reduced cotton lint production by 0.5 bale/acre or more. Abo Zeid et al. (1990) found that the least yield 
per feddan was obtained from uncultivated treatment, while increasing the number of cultivation from one up to three resulted in agradual increment in the yield per unit area which were 5.9, 10.4 and $18.4 \%$ from one, two and three cultivation, respectively, and similar trends were obtained with yield components. Klingaman and Oliver (1994), found that losses in cotton yield increased from 30 to 50 percent when weed density increased from 1.7 to $6.7 \mathrm{~m}^{-1}$ and the yield losses vary depending on weed density or weed species. Abd-El-Rehim et al. (1995) showed that fiber properties of cotton were generally less sensitive to herbicidal treatments than the vegetative, fruiting and yield characteristics. Abd-El-Rehim et al. (1996) found that fiber length at $50 \%$ and $2.5 \%$ S.L, micronaire reading, fiber strength, uniformity ratio and fiber elongation were not significantly affected by either hand hoeing or the various herbicidal treatments. However, fiber strength at zero and 1/8 inch gauge length, fiber stiffness, fiber toughness and yarn strength were significantly increased by hand hoeing or different herbicidal treatments. Ferrel et al. (2001), in India, found that the infestation of weed flora in cotton crop reduced the yield by 1.28 and 1.6 ton/ha from weed free cotton fields, and the severity of weed competition depended on weed densities and their composition. Bukun (2004), in Turky, found that weeds should be eliminated from 1-2 weeks up to 11-12 weeks of plant emergence and weed control strategies should be done in these periods. Soliman et al. (2014) mentioned that boll weight, position of the $1^{\text {st }}$ sympodial node, fiber length, fiber strength and micronaire reading were not affected by weed control.

The objective of this study was to determine the effect of critical period of weeds on growth, yield and its components and fiber properties of Egyptian cotton Giza 86 cultivar in the newly reclaimed calcareous soil of Nubaria, Behera Governorate.

\section{MATERIALS AND METHODS}

Two field experiments were conducted in Nubaria Agricultural Research Station, Behera Governorate, Egypt during the two growing seasons 2012 and 2013 in calculus soil. The soil texture was sandy texture. Table (1) shows the mechanical and chemical analyses of the soil.

The experimental design was a complete randomized block design with four replications. The fourteen treatments were divided into two groups; the first group included seven weed-free periods namely; 1 - Weed-free for the 3 weeks from sowing. 2- Weed-free for the 6 weeks from sowing. 3- Weed-free for the 9 weeks from sowing. 4- Weed-free for the 12 weeks from sowing. 5- Weed-free for the 15 weeks from sowing. 6- Weed-free for the 18 weeks from sowing. 7- Weed-free for the whole season. while the second group included seven weed competition periods namely; 8- Weed competition for 3 weeks from sowing. 9- Weed competition for 6 weeks from sowing. 10- Weed competition for 9 weeks from sowing. 11- Weed competition for 12 weeks from sowing. 12Weed competition for 15 weeks from sowing. 13- Weed competition for 18 weeks from sowing. 14- Weed competition for the whole season.

The area of each plot was $16.25 \mathrm{~m}^{2}$ (including five ridges each of $0.65 \mathrm{~m}$ wide $\times 5 \mathrm{~m}$ length). Distance between hills was $25 \mathrm{~cm}$. Cotton seeds of the Egyptian long staple cotton cultivar Giza 86 were sown on 17 and 22 April after two cuts of Egyptian clover in both seasons, respectively. Cotton plants were irrigated, eight times during the whole growing season, in addition to sowing irrigation. The first irrigation was applied after 21 days from sowing, while the other seven irrigations were given at 15-days intervals. Before the second irrigation, the plants were thinned to two plants/hill.

Phosphorus in the form of super phosphate $\left(\begin{array}{lll}15.5 \% & \mathrm{P}_{2} 0_{5}\end{array}\right)$ was applied during land preparation at the rate of $31 \mathrm{~kg} \mathrm{P}_{2} \mathrm{O}_{5} /$ feddan.

Table (1): Soil mechanical and chemical analysis of soil of the upper $50 \mathrm{~cm}$ depth in 2012 and 2013 seasons.

\begin{tabular}{|c|c|c|c|c|c|}
\hline \multicolumn{2}{|c|}{ Mechanical analysis } & \multicolumn{2}{c|}{ Chemical analysis } \\
\hline Analysis & $\mathbf{2 0 1 2}$ & $\mathbf{2 0 1 3}$ & Analysis & $\mathbf{2 0 1 2}$ & $\mathbf{2 0 1 3}$ \\
\hline Sand \% & 21.06 & 22.16 & Caco $_{3}$ content \% & 2.55 & 2.60 \\
Silt \% & 34.71 & 35.07 & Organic matter \% & 0.92 & 0.94 \\
Clay \% & 44.23 & 42.77 & PH & 7.7 & 7.8 \\
Soil texture & Clay & Clay & EC dm/m (1:5 ext.) & 0.90 & 0.92 \\
\hline
\end{tabular}


Average yearly nitrogen fertilizer rate for cotton was $75 \mathrm{Kg} \mathrm{N} /$ feddan of ammonium nitrate $(33.5 \% \mathrm{~N})$ was applied in two equal doses (37.5 $+37.5 \mathrm{Kg} \mathrm{N} /$ feddan), i.e., the first dose after thinning and before the second irrigation, the second dose before the third irrigation. Potassium sulphate $\left(48 \% \mathrm{~K}_{2} \mathrm{O}\right)$ was applied at the rate of $24 \mathrm{Kg} \mathrm{K}_{2} \mathrm{O} /$ feddan after thinning. The other standard agricultural practices were followed throughout the growing seasons.

\subsection{Data recorded}

2.1.1. Fresh weight of weeds $\left(\mathrm{g} / \mathrm{m}^{2}\right)$ : For weedfree periods, plots were kept free from weeds for $3,6,9,12,15,18$ weeks and for whole season (treatments 1-7) and after that weeds were allowed to compete with the cotton plants for the remainder time of the season till harvest. In weed interference (competition) periods, normal weed populations were allowed to emerge and compete with cotton plants for 3, 6, 9, 12, 15, 18 weeks and for the whole season (treatments 8 14). Weeds were hand pulled at random from one square meter of each plot and classified into three categories, broad leaf weeds, grassy weeds and total weeds according to Tackholm (1974).

2.1.2. Growth attributes: In both seasons, five representative hills (10 plants/plot) were taken at random in order to study the following traits:

(1) Plant height at harvest $(\mathrm{cm})$, measured from soil surface to the top of the plant (2) position of the $1^{\text {st }}$ sympodial node, (3) Number of sympodial branches/plant, (4) Number of monopodial branches/plant, (5) Number of open bolls/plant and (6) Number of non open bolls/plant.

2.1.3. Yield and its components: At harvest, ten plants were randomly taken from the inner ridges of each plot to measure the following data:

Boll weight (g), seed cotton yield/plant (g), seed cotton yield quintar $/$ feddan (quintar $=157.5 \mathrm{~kg}$ ), lint percentage (= weight of lint/weight of seed cotton $\times 100$ ), lint cotton yield quintar/feddan (quintar $=50 \mathrm{~kg}$ ).

Seed index $=$ The weight of 100 seed in gram.

2.1.4. Fiber Properties: Fiber properties were determined in Cotton Technology Research Division, Cotton Research Institute, Agricultural Research Center, Giza, Egypt, at constant relative humidity of $65 \% \pm 2$ and temperature of $21^{\circ} \mathrm{C} \pm 2$ on random samples of cotton lint, by using High Volume Instrument (HVI) according to (A.S.T.M.1984 D-4605-86), for the following traits: 1. Fiber length parameters: Upper half means (U.H.M) and Uniformity index (U.I)., 2. Fiber bundle tensile: Fiber strength (g/tex.) and
Fiber elongation percentage (\%). 3. Micronaire reading: (which denote fiber fineness and maturity in combination) and 4. Lint Colour measurements: Reflectance (Rd \%) and Yellowness (+b).

The obtained data of each season were subjected to statistical analysis according to Snedecor and Cochran (1980) then a combined analysis for the two seasons was done and L.S.D. values at $5 \%$ level of significance were used for comparison between means.

\section{RESULTS AND DISCUSSION}

The most dominant weeds in the experimental fields were wild jute (Corchorns olitorius L.), cochlebur (Xanthium brasilicum L.), white goosefoot (Amaranthus album L.), common purslane (Portulaca olerceae L.) and black nightshade (Solanum nigrum L.) as broad leaf weeds and deccan grass (Echionchloa colona L.), panz (Dinebra retroflexa L.) and bermuda grass (Cynodon dactylon L.) as grassy weeds in both 2012 and 2013 seasons.

The results of weed removal periods on weeds, growth, seed cotton yield/faddan and its components and fiber properties for Giza 86 variety during 2012 and 2013 seasons are discussed as follow:

\subsection{Effect of weed removal and weed competition periods on weeds}

Table (2) shows the average of combined analysis of the effect of weed removal and weed competition periods on total weed infestation (fresh weight $\left.\mathrm{g} / \mathrm{m}^{2}\right)$. The fresh weight $\left(\mathrm{g} / \mathrm{m}^{2}\right)$ of broad leaf weeds, grassy weeds and total annual weeds were decreased gradually by increasing of weed removal periods which estimated by 14.3, 23.0 and $17.5 \%$ with the treatment of weed-free for 3 weeks from sowing, respectively and 93.1, 93.7 and $93.3 \%$ with the treatment of weed-free for 18 weeks from sowing, respectively, as compared with weed competition for the whole season treatment.

3.2. Effect of weed removal and weed competition periods on cotton growth

Data in Table (3) indicated that, the effect of weed removal and weed competition periods were not statistically significant on the position of the $1^{s t}$ sympodial node, number of open bolls/plant and the number of non open bolls/plant in both seasons, meanwhile arrived to the level of significance on the plant height, number of sympodial and monopodial branches/plant. The cotton plants height tended to decrease gradually with increasing weed 
Table (2): The effect of weed removal and weed competition periods on weed infestation (fresh weight combined analysis of 2012 and $2013 \mathrm{seasons} \mathrm{g} / \mathrm{m}^{2}$ ).

\begin{tabular}{|c|c|c|c|c|c|c|c|c|c|}
\hline $\begin{array}{l}\text { Weed removal } \\
\text { durations }\end{array}$ & $\begin{array}{l}\text { Broad leaf weeds } \\
\mathrm{g} / \mathrm{m}^{2}\end{array}$ & $\begin{array}{l}\text { Narrow leaf } \\
\text { weeds } g / \mathbf{m}^{2}\end{array}$ & $\begin{array}{c}\text { Total weight of } \\
\text { weeds } \mathbf{g} / \mathrm{m}^{2}\end{array}$ & $\begin{array}{c}\% \\
\text { Reduction }\end{array}$ & $\begin{array}{c}\text { Weed competition } \\
\text { durations }\end{array}$ & $\begin{array}{c}\text { Broad leaf } \\
\text { weeds } \mathrm{g} / \mathrm{m}^{2}\end{array}$ & $\begin{array}{l}\text { Narrow leaf } \\
\text { weeds } g / \mathrm{m}^{2}\end{array}$ & $\begin{array}{c}\text { Total weight } \\
\text { of weeds } \mathrm{g} / \mathrm{m}^{2}\end{array}$ & $\begin{array}{c}\% \\
\text { Reduction }\end{array}$ \\
\hline $\begin{array}{l}\text { Weed-free } \\
\text { for } 3 \text { weeks }\end{array}$ & 1930.5 & 1026 & 2956.5 & 17.5 & $\begin{array}{l}\text { Weed competition } \\
\text { for } 3 \text { weeks }\end{array}$ & 52.2 & 33.5 & 85.7 & 97.6 \\
\hline $\begin{array}{l}\text { Weed-free } \\
\text { for } 6 \text { weeks }\end{array}$ & 1651.2 & 708.8 & 2360 & 34.1 & $\begin{array}{l}\text { Weed competition } \\
\text { for } 6 \text { weeks }\end{array}$ & 78.2 & 36.8 & 115 & $\begin{array}{l}96.8 \\
\end{array}$ \\
\hline $\begin{array}{l}\text { Weed-free } \\
\text { for } 9 \text { weeks }\end{array}$ & 1430.7 & 697 & 2127.7 & 40.6 & $\begin{array}{l}\text { Weed competition } \\
\text { for } 9 \text { weeks }\end{array}$ & 80.3 & 34 & 114.3 & 96.8 \\
\hline $\begin{array}{l}\text { for } 12 \text { weeks } \\
\text { Weed-free }\end{array}$ & 1073.2 & 413 & 1486.2 & 58.5 & $\begin{array}{l}\text { Weed competition } \\
\text { for12 weeks }\end{array}$ & 90.8 & 56 & 146.8 & 96 \\
\hline $\begin{array}{l}\text { for } 15 \text { weeks } \\
\text { Weed-free }\end{array}$ & 682.5 & 307.2 & 989.7 & 72.4 & $\begin{array}{l}\text { Weed competition } \\
\text { for } 15 \text { weeks }\end{array}$ & 120.3 & 63.8 & 184.1 & 94.9 \\
\hline $\begin{array}{l}\text { for } 18 \text { weeks } \\
\text { Weed-free }\end{array}$ & 156 & 84.5 & 240.5 & 93.3 & $\begin{array}{l}\text { Weed competition } \\
\text { for } 18 \text { weeks }\end{array}$ & 170.3 & 87.8 & 258.1 & 92.8 \\
\hline for the whole season & 6.8 & 15.7 & 22.5 & 99.4 & $\begin{array}{l}\text { Weed-competition } \\
\text { for the whole } \\
\text { season (check) }\end{array}$ & 2251.7 & 1332.2 & 3583.9 & $\mathbf{0}$ \\
\hline LSD at $5 \%$ & 115.1 & 115.2 & 162.1 & & & 115.1 & 115.2 & 162.1 & \\
\hline
\end{tabular}


Effect of critical weed competition period on yield and

Table (3): Effect of weed removal and weed competition periods on growth attributes (combined analysis 2012 and 2013 seasons).

\begin{tabular}{|c|c|c|c|c|c|c|c|c|c|c|c|c|c|}
\hline $\begin{array}{l}\text { Weed removal } \\
\text { durations }\end{array}$ & $\begin{array}{l}\text { Plant } \\
\text { height } \\
(\mathrm{cm})\end{array}$ & $\begin{array}{c}\text { Position } \\
\text { of } 1^{\text {st }} \\
\text { sympodial } \\
\text { node }(\mathrm{cm})\end{array}$ & $\begin{array}{c}\text { No. of } \\
\text { sympodial } \\
\text { branches } \\
\text { /plant }\end{array}$ & $\begin{array}{c}\text { No. of } \\
\text { monopodial } \\
\text { branches/ } \\
\text { plant }\end{array}$ & $\begin{array}{l}\text { No. of } \\
\text { open } \\
\text { bolls/ } \\
\text { plant }\end{array}$ & $\begin{array}{c}\text { No. of non } \\
\text { open } \\
\text { bolls/ } \\
\text { plant }\end{array}$ & $\begin{array}{c}\text { Weed competition } \\
\text { durations }\end{array}$ & $\begin{array}{l}\text { Plant } \\
\text { height } \\
(\mathrm{cm})\end{array}$ & $\begin{array}{c}\text { Position } \\
\text { of } 1^{\text {st }} \\
\text { sympodial } \\
\text { node (cm) }\end{array}$ & $\begin{array}{c}\text { No. of } \\
\text { sympodial } \\
\text { branches } \\
\text { /plant }\end{array}$ & $\begin{array}{c}\text { No. of } \\
\text { monopodial } \\
\text { branches/ } \\
\text { plant }\end{array}$ & $\begin{array}{c}\text { No. of } \\
\text { open } \\
\text { bolls/ } \\
\text { plant }\end{array}$ & $\begin{array}{c}\text { No. of } \\
\text { non open } \\
\text { bolls/ } \\
\text { plant }\end{array}$ \\
\hline $\begin{array}{lll}\text { Weed-free } & \text { for } & 3 \\
\text { weeks } & & \end{array}$ & 128.3 & 7.67 & 15.5 & 4.83 & 10.33 & 4.00 & $\begin{array}{l}\text { Weed competition } \\
\text { for } 3 \text { weeks }\end{array}$ & 110.2 & 8.67 & 16.8 & 2.00 & 15.00 & 3.50 \\
\hline $\begin{array}{l}\text { Weed-free for } 6 \\
\text { weeks }\end{array}$ & 129.2 & 8.17 & 16.3 & 1.67 & 13.67 & 5.17 & $\begin{array}{l}\text { Weed competition } \\
\text { for } 6 \text { weeks }\end{array}$ & 118.5 & 8.50 & 18.5 & 1.50 & 12.83 & 4.00 \\
\hline $\begin{array}{l}\text { Weed-free for } 9 \\
\text { weeks }\end{array}$ & 118.7 & 8.33 & 12.3 & 1.50 & 10.67 & 3.17 & $\begin{array}{l}\text { Weed competition } \\
\text { for } 9 \text { weeks }\end{array}$ & 124.0 & 8.50 & 18.0 & 1.67 & 14.00 & 2.83 \\
\hline $\begin{array}{l}\text { Weed-free for } 12 \\
\text { weeks }\end{array}$ & 109.2 & 8.67 & 12.8 & 0.50 & 12.50 & 3.17 & $\begin{array}{l}\text { Weed competition } \\
\text { for } 12 \text { weeks }\end{array}$ & 117.2 & 8.50 & 13.8 & 1.33 & 12.50 & 4.00 \\
\hline $\begin{array}{l}\text { Weed-free for } 15 \\
\text { weeks }\end{array}$ & 105.7 & 9.00 & 11.5 & 0.83 & 12.83 & 3.33 & $\begin{array}{l}\text { Weed competition } \\
\text { for } 15 \text { weeks }\end{array}$ & 103.5 & 8.17 & 12.8 & 1.00 & 11.67 & 3.17 \\
\hline $\begin{array}{l}\text { Weed-free for } 18 \\
\text { weeks }\end{array}$ & 98.7 & 8.83 & 12.0 & 1.00 & 9.50 & 3.67 & $\begin{array}{l}\text { Weed competition } \\
\text { for } 18 \text { weeks }\end{array}$ & 104.5 & 9.00 & 12.2 & 0.83 & 11.17 & 2.67 \\
\hline $\begin{array}{l}\text { Weed-free for the } \\
\text { whole season }\end{array}$ & 102.2 & 8.50 & 12.8 & 1.67 & 12.00 & 2.50 & $\begin{array}{l}\text { Weed-competition } \\
\text { for the whole } \\
\text { season (check) }\end{array}$ & 84.2 & 8.50 & 11.3 & 0.67 & 8.83 & 3.17 \\
\hline LSD at & 16.4 & NS & 2.12 & 0.76 & NS & NS & & 16.4 & NS & 2.12 & 0.76 & NS & NS \\
\hline
\end{tabular}


competition periods estimated by $17.6 \%$ from weed competition for the whole season than weed-free periods for the whole season and vice versa increased with increasing weed free periods. The same trend was obtained with the number of sympodial branches/plant which decreased significantly with increasing weed competition periods and reached to $11.7 \%$ with competition for the whole season as compared with free periods for the whole season. These results are in agreement with those obtained by Ghaly and El Shinnawy (1985) and Abo Zeid et al. (1990).

3.3. Effect of weed removal and weed competition periods on yield and its components

Data presented in Table (4) show that, the effect of weed removal and weed competition periods were not statistically significant on lint $\%$ and seed index. Also, data indicated that the effect of weed removal and weed competition periods were statistically significant on boll weight, seed cotton yield/plant, seed cotton yield (quintar/feddan) and lint cotton yield (quintar/feddan). Weed competition for the whole season reduced the seed cotton yield (quintar/feddan) by $41.1 \%$ as compared with weed-free for the whole season and shortening early weed competition from 18 weeks to 3 weeks increasing cotton seed yield (quintar/faddan) while, shortening the period of weed-free increased the reduction in seed cotton yield (quintar/feddan). Similar results were obtained by Kempen (1984) and Klingaman and Oliver (1994), who found that cotton yield losses increased from 30 to $50 \%$ when weed density increased from 1.7 to $6.7 \mathrm{~m}^{-1}$ of row, and Kempen (1984) found that several annual and perennial weeds reduced cotton lint production lees 0.5 bale $\mathrm{A}^{-1}$ or more.

Weed-free for the whole season gave the highest seed cotton yield (quintar/feddan) which increased by $17.3 \%$, as compared with weed-free for the first 3 weeks, while weed competition for the first 3 weeks gave the highest seed cotton yield (quintar/feddan) which surpassed by $45.2 \%$, as compared with weed competition for the whole season. Both early and late competition treatments did not cause significant effect on lint \%. These results are in agreement with those obtained by Mohamed et al. (1989) and Soliman et al. (2014). In general, the increase in seed cotton yield per feddan is attributed to the increase in seed cotton yield per plant and boll weight owing to minimizing weed competition and consequently improve cotton plants to utilize from environmental resources.

3.4. Effect of weed removal and weed competition periods on fiber properties

Data in Tables (5 a and b) indicated that, all the studied fiber properties namely; fiber length, fiber uniformity index, fiber elongation, micronaire reading, reflectance ( $\mathrm{Rd} \%)$ and Yellowness $(+b)$ were not statistically affected by weed removal and weed competition period treatments in the average analysis of the two seasons except fiber strength. These results are in agreement with those obtained by $\mathrm{Abd} \mathrm{El}$ Rehim et al. (1995). They found that fiber length, micronaire reading, uniformity ratio and fiber elongation were not affected by hand hoeing and Soliman et al. (2014), who mentioned that fiber length and micronaire reading were not affected by weed control treatments.

** Determination Critical period of weed competition to cotton

Fig. (1) shows the relationship between weed-free and weed competition periods on seed cotton yield per feddan. It is clear that the beginning of critical period starts after one month from sowing and ended at 18 weeks from

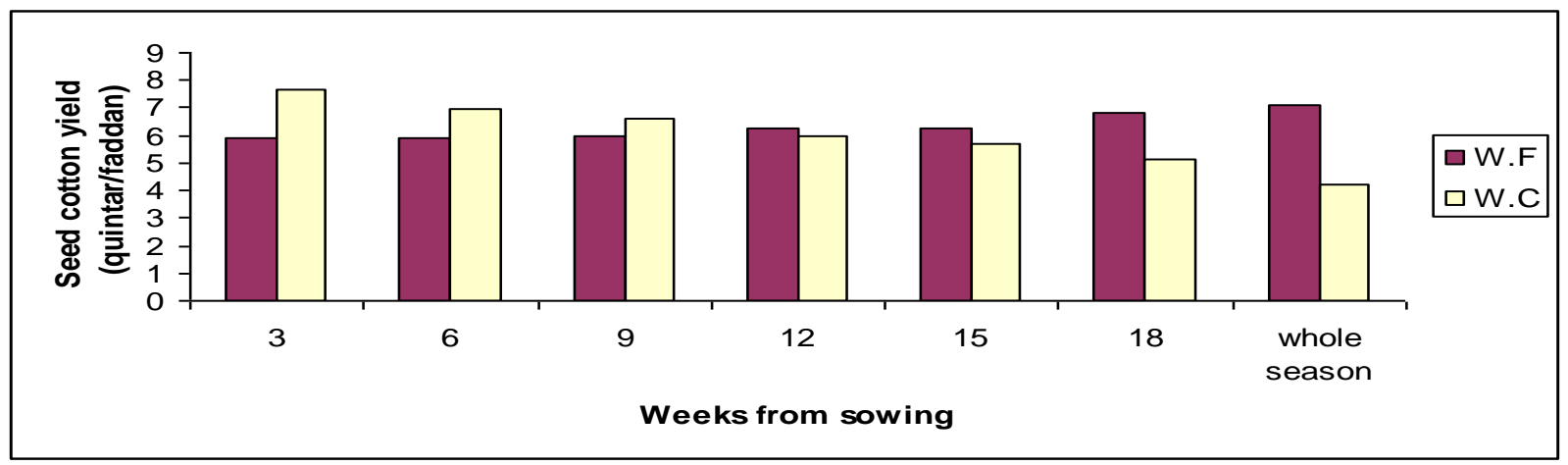

Fig. (1): Effect of weed-free (W.F) and weed competition (W.C) on seed cotton yield (quintar/feddan combined analysis of 2012 and 2013 seasons). 
Table (4): Effect of weed removal and weed competition periods on seed cotton yield and its components of cotton (combined analysis of 2012 and 2013 seasons).

\begin{tabular}{|c|c|c|c|c|c|c|c|c|c|c|c|c|c|}
\hline $\begin{array}{l}\text { Weed removal } \\
\text { durations }\end{array}$ & $\begin{array}{c}\text { Boll } \\
\text { weight } \\
(\mathrm{g})\end{array}$ & $\begin{array}{c}\text { Seed } \\
\text { cotton } \\
\text { yield / } \\
\text { plant } \\
(\mathrm{g})\end{array}$ & $\begin{array}{c}\text { Seed } \\
\text { cotton } \\
\text { yield / } \\
\text { feddan } \\
\text { (quintar) }\end{array}$ & $\begin{array}{c}\text { Lint } \\
\%\end{array}$ & $\begin{array}{c}\text { Lint } \\
\text { cotton } \\
\text { yield } \\
\text { feddan } \\
\text { (quintar) }\end{array}$ & $\begin{array}{l}\text { Seed } \\
\text { Index } \\
(\mathrm{g})\end{array}$ & $\begin{array}{c}\text { Weed competition } \\
\text { durations }\end{array}$ & $\begin{array}{c}\text { Boll } \\
\text { weight } \\
(\mathrm{g})\end{array}$ & $\begin{array}{c}\text { Seed } \\
\text { cotton } \\
\text { yield / } \\
\text { plant(g) }\end{array}$ & $\begin{array}{c}\text { Seed } \\
\text { cotton } \\
\text { yield / } \\
\text { feddan } \\
\text { (quintar) }\end{array}$ & $\begin{array}{c}\text { Lint } \\
\%\end{array}$ & $\begin{array}{c}\text { Lint } \\
\text { cotton } \\
\text { yield } \\
\text { feddan } \\
\text { (quintar) }\end{array}$ & $\begin{array}{c}\text { Seed } \\
\text { Index } \\
(\mathrm{g})\end{array}$ \\
\hline $\begin{array}{c}\text { Weed-free for } 3 \\
\text { weeks }\end{array}$ & 1.73 & 18.02 & 5.90 & 38.6 & 7.12 & 9.62 & $\begin{array}{l}\text { Weed competition for } \\
3 \text { weeks }\end{array}$ & 1.81 & 28.17 & 7.67 & 38.2 & 9.23 & 10.38 \\
\hline $\begin{array}{l}\text { Weed-free for } 6 \\
\text { weeks }\end{array}$ & 1.83 & 25.30 & 5.94 & 38.4 & 7.22 & 10.01 & $\begin{array}{c}\text { Weed competition for } \\
6 \text { weeks }\end{array}$ & 1.68 & 20.88 & 6.97 & 37.8 & 8.32 & 10.20 \\
\hline $\begin{array}{l}\text { Weed-free for } 9 \\
\text { weeks }\end{array}$ & 1.60 & 17.60 & 6.00 & 38.5 & 7.20 & 9.96 & $\begin{array}{l}\text { Weed competition for } \\
9 \text { weeks }\end{array}$ & 1.55 & 22.18 & 6.60 & 38.4 & 7.98 & 9.64 \\
\hline $\begin{array}{c}\text { Weed-free for } 12 \\
\text { weeks }\end{array}$ & 1.55 & 18.70 & 6.24 & 38.3 & 7.57 & 9.83 & $\begin{array}{l}\text { Weed competition for } \\
12 \text { weeks }\end{array}$ & 1.90 & 24.58 & 5.98 & 37.9 & 7.12 & 9.94 \\
\hline $\begin{array}{c}\text { Weed-free for } 15 \\
\text { weeks }\end{array}$ & 1.78 & 23.20 & 6.27 & 38.4 & 7.52 & 9.92 & $\begin{array}{l}\text { Weed competition for } \\
15 \text { weeks }\end{array}$ & 1.63 & 18.86 & 5.73 & 37.1 & 6.86 & 9.93 \\
\hline $\begin{array}{c}\text { Weed-free for } 18 \\
\text { weeks }\end{array}$ & 1.84 & 17.73 & 6.82 & 38.1 & 8.25 & 10.20 & $\begin{array}{l}\text { Weed competition for } \\
18 \text { weeks }\end{array}$ & 1.67 & 19.07 & 5.14 & 38.3 & 6.20 & 9.93 \\
\hline $\begin{array}{l}\text { Weed-free for the } \\
\text { whole season }\end{array}$ & 1.60 & 19.68 & 7.13 & 38.1 & 8.62 & 9.53 & $\begin{array}{c}\text { Weed-competition for } \\
\text { the whole season } \\
\text { (check) }\end{array}$ & 1.46 & 12.83 & 4.20 & 38.3 & 5.07 & 10.20 \\
\hline LSD at $5 \%$ & 0.12 & 7.13 & 0.54 & NS & 0.22 & NS & & 0.12 & 7.13 & 0.54 & NS & 0.22 & NS \\
\hline
\end{tabular}


Table (5a): Effect of weed removal and weed competition periods on fiber properties of cotton (combined analysis of 2012 and 2013 seasons).

\begin{tabular}{|c|c|c|c|c|c|c|c|c|c|}
\hline $\begin{array}{l}\text { Weed removal } \\
\text { durations }\end{array}$ & $\begin{array}{l}\text { Fiber length } \\
\quad(\mathrm{mm})\end{array}$ & $\begin{array}{c}\text { Uniformity } \\
\text { Index } \\
\%\end{array}$ & $\begin{array}{l}\text { Fiber } \\
\text { strength } \\
\text { g/tex. }\end{array}$ & $\begin{array}{c}\text { Fiber } \\
\text { elongation } \\
\%\end{array}$ & $\begin{array}{l}\text { Weed competition } \\
\text { durations }\end{array}$ & $\begin{array}{l}\text { Fiber length } \\
\text { (mm) }\end{array}$ & $\begin{array}{l}\text { Uniformity } \\
\text { Index \% }\end{array}$ & $\begin{array}{c}\text { Fiber strength } \\
\text { g/tex. }\end{array}$ & $\begin{array}{c}\text { Fiber elongation } \\
\%\end{array}$ \\
\hline $\begin{array}{l}\text { Weed-free for } \\
3 \text { weeks }\end{array}$ & 32.87 & 85.77 & 44.37 & 7.32 & $\begin{array}{l}\text { Weed competition } \\
\text { for } 3 \text { weeks }\end{array}$ & 32.48 & 86.57 & 46.43 & 7.45 \\
\hline $\begin{array}{l}\text { Weed-free for } \\
6 \text { weeks }\end{array}$ & 32.72 & 84.95 & 45.00 & 7.35 & $\begin{array}{l}\text { Weed competition } \\
\text { for } 6 \text { weeks }\end{array}$ & 32.72 & 86.30 & 46.00 & 7.37 \\
\hline $\begin{array}{l}\text { Weed-free for } \\
9 \text { weeks }\end{array}$ & 32.77 & 85.60 & 45.32 & 7.38 & $\begin{array}{l}\text { Weed competition } \\
\text { for } 9 \text { weeks }\end{array}$ & 32.67 & 86.07 & 45.18 & 7.40 \\
\hline $\begin{array}{l}\text { Weed-free for } \\
12 \text { weeks }\end{array}$ & 32.28 & 87.15 & 45.25 & 7.32 & $\begin{array}{l}\text { Weed competition } \\
\text { for } 12 \text { weeks }\end{array}$ & 32.77 & 86.05 & 45.33 & 7.37 \\
\hline $\begin{array}{l}\text { Weed-free for } \\
15 \text { weeks }\end{array}$ & 32.67 & 86.00 & 45.35 & 7.33 & $\begin{array}{l}\text { Weed competition } \\
\text { for } 15 \text { weeks }\end{array}$ & 32.67 & 86.47 & 46.55 & 7.43 \\
\hline $\begin{array}{l}\text { Weed-free for } \\
18 \text { weeks }\end{array}$ & 32.28 & 86.65 & 45.12 & 7.38 & $\begin{array}{l}\text { Weed competition } \\
\text { for } 18 \text { weeks }\end{array}$ & 32.63 & 85.72 & 46.97 & 7.38 \\
\hline $\begin{array}{l}\text { Weed-free for } \\
\text { the whole } \\
\text { season }\end{array}$ & 32.60 & 86.62 & 46.77 & 7.50 & $\begin{array}{l}\text { Weed-competition } \\
\text { for the whole season } \\
\text { (check) }\end{array}$ & 32.27 & 85.98 & 46.38 & 7.38 \\
\hline LSD at $\quad 5 \%$ & NS & NS & 1.49 & NS & & NS & NS & 1.49 & NS \\
\hline
\end{tabular}

Table (5b): Effect of weed removal and weed competition periods on fiber properties of cotton (combined analysis of 2012 and 2013 seasons).

\begin{tabular}{|c|c|c|c|c|c|c|c|}
\hline $\begin{array}{c}\text { Weed removal } \\
\text { durations }\end{array}$ & $\begin{array}{l}\text { Micronaire } \\
\text { reading }\end{array}$ & $\begin{array}{l}\text { Reflectance } \\
\text { Rd \% }\end{array}$ & $\begin{array}{c}\text { Yellowness } \\
(+\mathbf{b})\end{array}$ & $\begin{array}{c}\text { Weed competition } \\
\text { durations }\end{array}$ & $\begin{array}{c}\text { Micronaire } \\
\text { reading }\end{array}$ & $\begin{array}{l}\text { Reflectance } \\
\text { Rd \% } \\
\end{array}$ & $\begin{array}{c}\text { Yellowness } \\
(+b)\end{array}$ \\
\hline $\begin{array}{c}\text { Weed-free } \\
\text { for } 3 \text { weeks }\end{array}$ & 4.70 & 74.03 & 9.48 & $\begin{array}{l}\text { Weed competition } \\
\text { for } 3 \text { weeks }\end{array}$ & 4.63 & 75.05 & 9.18 \\
\hline $\begin{array}{l}\text { Weed-free } \\
\text { for } 6 \text { weeks }\end{array}$ & 4.68 & 74.58 & 9.22 & $\begin{array}{l}\text { Weed competition } \\
\text { for } 6 \text { weeks }\end{array}$ & 4.72 & 74.80 & 9.22 \\
\hline $\begin{array}{l}\text { Weed-free } \\
\text { for } 9 \text { weeks }\end{array}$ & 4.73 & 75.33 & 9.30 & $\begin{array}{l}\text { Weed competition } \\
\text { for } 9 \text { weeks }\end{array}$ & 4.73 & 75.95 & 9.15 \\
\hline $\begin{array}{l}\text { Weed-free } \\
\text { for } 12 \text { weeks }\end{array}$ & 4.73 & 74.90 & 9.35 & $\begin{array}{l}\text { Weed competition } \\
\text { for } 12 \text { weeks }\end{array}$ & 4.67 & 75.30 & 9.23 \\
\hline $\begin{array}{l}\text { Weed-free } \\
\text { for } 15 \text { weeks }\end{array}$ & 4.72 & 75.23 & 9.15 & $\begin{array}{l}\text { Weed competition } \\
\text { for } 15 \text { weeks }\end{array}$ & 4.63 & 74.00 & 9.13 \\
\hline $\begin{array}{c}\text { Weed-free } \\
\text { for } 18 \text { weeks }\end{array}$ & 4.47 & 74.85 & 9.00 & $\begin{array}{l}\text { Weed competition } \\
\text { for } 18 \text { weeks }\end{array}$ & 4.67 & 74.77 & 9.28 \\
\hline $\begin{array}{c}\text { Weed-free } \\
\text { for the whole season }\end{array}$ & 4.58 & 75.72 & 9.10 & $\begin{array}{c}\text { Weed-competition for } \\
\text { the whole season } \\
\text { (check) }\end{array}$ & 4.70 & 74.48 & 9.38 \\
\hline $\begin{array}{l}\text { LSD at } \quad \mathbf{5 \%} \\
\end{array}$ & NS & NS & NS & & NS & NS & NS \\
\hline
\end{tabular}


month from sowing and ended at 18 weeks from sowing and the critical point of weed competition where seed cotton yield losses from weed competition and weed free periods lie in the fifteen week from sowing. These results suggest that cotton affected significantly for prolonged period of weed competition (15 weeks) and this need strategies of weed control in this period to maximize seed cotton yield production. These results confirm the results obtained by Bukun (2004).

\section{Conclusion}

The obtained results throw lights about the magnitude of weed competition problem which cause $41.1 \%$ yield reduction from competition for the whole season and planning weed management strategies through 15 weeks from planting without any adverse effect on fiber properties for cotton Giza 86 cultivar under Nubaria Agricultural Research Station conditions, Behera Governorate.

\section{REFERENCES}

Abd El-Rehim Salwa A., Afifi A. H. A. and Saad El-Din S. A. (1995). Effect of some herbicides on physical and mechanical properties of fibers, growth and yield in Egyptian cotton Egypt. J. Appl. Sci., 10 (2): 512-524.

Abd El-Rehim S. A., Saad El-Din S. A. and Afifi A. H. A. (1996). Comparative study on the effect of hand hoeing and different herbicidal treatments on physical properties of fiber and yarn growth and yield in Egyptian cotton. J. Agric. Sci. Mansoura Univ., 21 (7): 2473-2483.

Anonymous (2014). Brief of Agricultural Statistics, Arab Republic of Egypt, Ministry of Agricultural and Land Reclamation.

ASTM (1984). American society for testing and materials. Standards on textile materials. D: 1447-83, D: 1448-74 and D: 1445-75.

Abo-Zeid H. M., Ghaly F. M., El-Razzaz M. M., Abd El-Kader A. E. and Abdel-Malek K. I. (1990). Compatibility of herbicides and mechanical inter-row cultivation in cotton. Annals Agric. Sci. Moshtohor, 28(1): 133145.

Buchanan G. A. and Burns E. R. (1971). Weed competitions in cotton. Weed Sci.,19: 580-582.11.

Bukun B. (2004). Critical periods for weed control in cotton in Turkey. Weed Res., 44, 404-412.

Ferrell J. A., Mac Donald G. E. and Brecke B. J. (2001). Weed management in cotton 2006. Univ. of Florida IFSA Extension, pp, 1-32. (F.F Asian J. of plant Sci. 6(2): 344-348. (2007).

Ghaly F. M. and El Shinnawy A. H. (1985). The additional effect of hand-weeding and herbicides on Egyptian cotton and associated weeds. J. Agric. Res., Tanta Univ., 11 (3): 640:652.

Keeley P. E. and Thullen R. J. (1975). Influence of yellow nutsedge competition on furrow-irrigated cotton. Weed Sci., 23: 171-175.

Keeley P. E., Carter C. H. and Miller J. H. (1973). Yellow nutsedge and cotton response to several herbicides. Weed Sci., 21: 327-329.

Kempen H. M. (1984). Cotton production losses from weed competition in Kern Country: A three year evaluation. Proc,. West Soc. Weed Sci. 37: 47-51.

Klingaman T. E. and Olivar L. R. (1994). Influence of cotton (Gossypium hirsutum) and soybean (Glycine max) planting date on weed interference. Weed Sci., 42: 6165.

Mohamed H. M. H., Hosny A. A. and Abd ElAal H. A. (1989). Effect of water stress and hoeing on yield and yield components of Giza 75 cotton variety. Annals of Agric. Sci. Moshtohor, 27 (4) 2035-2051.

Snedecor G. W. and Cochran W. G. (1980). " Statistical Methods " $6^{\text {th }}$ ed., Iowa State Univ. Press, Ames. Iowa, U.S.A: 325-330.

Soliman I. E., Khaffagy A. E., Ghalwash A. M. and Abd El Aal A. S. (2014). Effect of some weed control packages on seed cotton yield and fiber properties of some cotton genotypes (Gossypium barbadense, L.) and its associated weeds. Egypt. T. Agric. Res., 92 (2): 605-623.

Tackholm V. (1974). Student's Flora of Egypt. $2^{\text {nd }}$ Ed. Cairo Univ., Egypt. Graphical Service, Beirut, Lebanon. 


\section{تأثير الفترة الحرجة لمنافسة الحشائش على محصول القطن وصفات التيلة فى الأراضى الجديدة \\ سعيد ضاحى محمد عيد - خالد عباس أبوزيد - مصطفى عطيه عمارة" \\ المعمل المركزى لبحوث الحشائشـ *معهد بحوث القطن- مركز البحوث الزر اعيةـ الجيزة- مصر.}

أقيمت تجربتان حقليتان فى أرض رملية كلسية طميية بمحطة البحوث الزبر الزية اعبة بالنوبارية - محافظة البحيرة

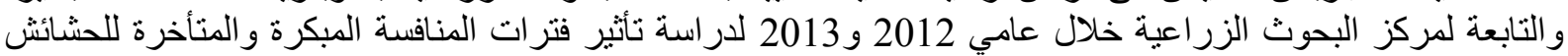

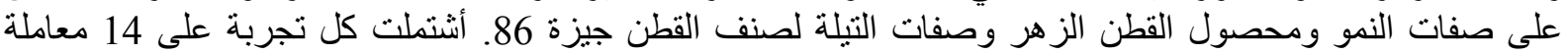

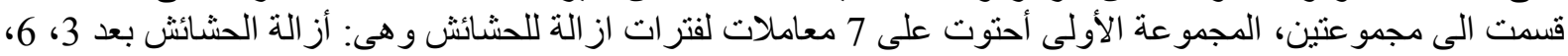

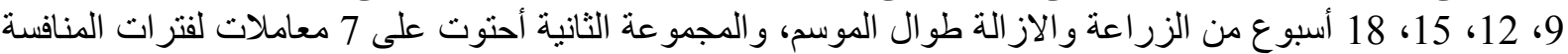

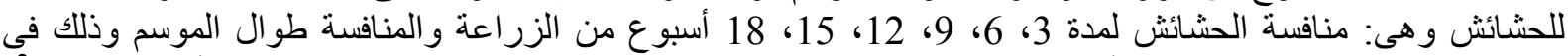

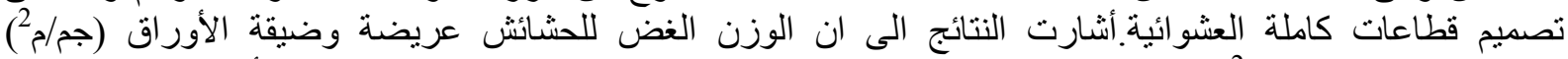

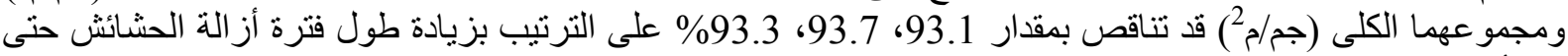

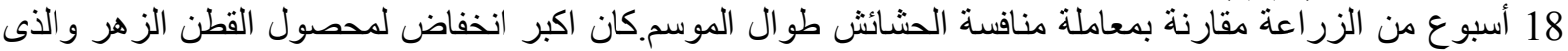

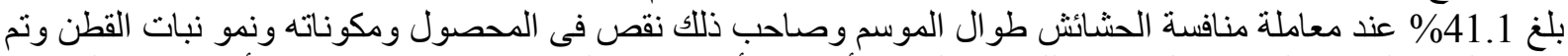

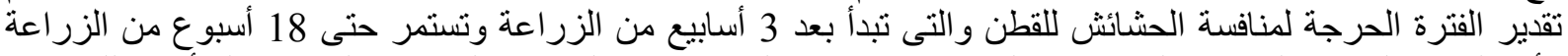

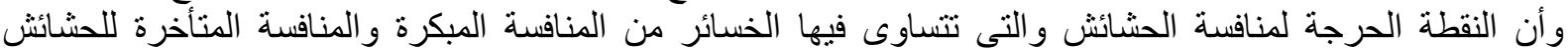

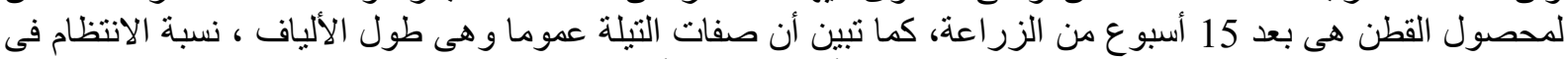

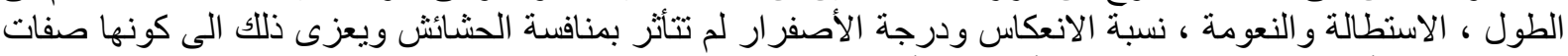

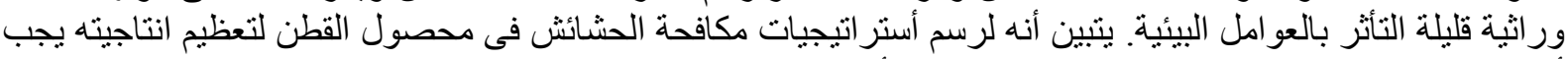

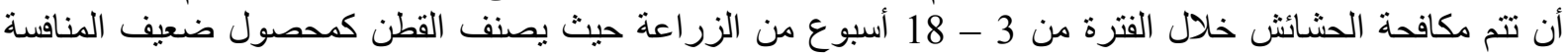
للحشّائش.

المجلة العلمية لكلية الزراعة ججامعة القاهرة ـ المجلد (67) العدد الاول (يناير 2016 ) : 9-18. 